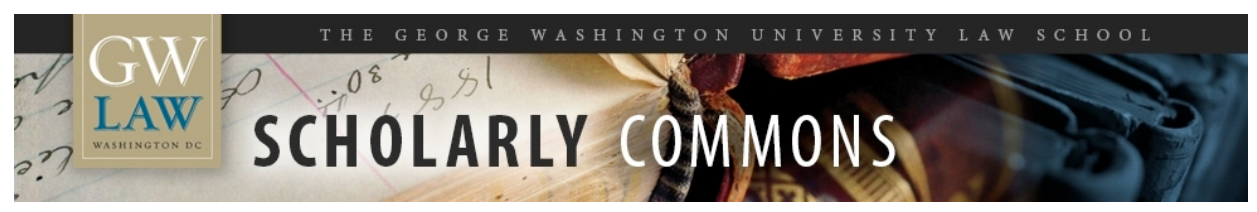

\title{
Setting the Record Straight: Three Concepts of the Independent Director
}

Donald C. Clarke

George Washington University Law School, dclarke@law.gwu.edu

Follow this and additional works at: https://scholarship.law.gwu.edu/faculty_publications

Part of the Law Commons

\section{Recommended Citation}

Clarke, Donald C., "Setting the Record Straight: Three Concepts of the Independent Director" (2006). GW Law Faculty Publications \& Other Works. 1066.

https://scholarship.law.gwu.edu/faculty_publications/1066

This Article is brought to you for free and open access by the Faculty Scholarship at Scholarly Commons. It has been accepted for inclusion in GW Law Faculty Publications \& Other Works by an authorized administrator of Scholarly Commons. For more information, please contact spagel@law.gwu.edu. 


\title{
SETTING THE RECORD STRAIGHT: THREE CONCEPTS OF THE INDEPENDENT DIRECTOR*
}

\author{
Donald C. Clarke \\ Professor of Law \\ George Washington University Law School \\ E-mail:dclarke@law.gwu.edu \\ Web site: donaldclarke.net
}

Draft date: March 17, 2006

\begin{abstract}
Despite the surprisingly shaky support in empirical research for the value of independent directors, their desirability seems to be taken for granted in policy-making circles. Yet important elements of the concept of and rationale for independent directors remain curiously obscure and unexamined. As a result, the empirical findings we do have may be misapplied, and judicial gap-filling may be harder than imagined when legislative intent cannot be divined or is contradictory.

This article attempts to unpack the concept broadly understood by the term "independent director" and to distinguish among its various concrete manifestations. In particular, I discuss the critical differences between independent, outside, and disinterested directors, arguing that these manifestations serve different purposes and should not be confused one with the other. This discussion is illustrated with examples from U.S. state and federal law as well as stock exchange regulations, and supplemented with comparative reference to the United Kingdom, Germany, and Japan, with a brief mention of Chinese practice as well. I also argue that the whole purpose of having independent directors is surprisingly undertheorized, leading to inconsistent rules, in particular regarding the effect of director shareholding, both across countries and within the United States.
\end{abstract}

* I would like to thank Sarah O'Sullivan of the George Washington University Law School for her assistance in the preparation of this article, as well as Professor Theresa Gabaldon for her thoughtful comments. 


\section{INTRODUCTION}

Independent directors have long been viewed as a solution to many corporate governance problems. Well before the Enron and WorldCom scandals, the New York Stock Exchange (NYSE) already required the presence of independent directors on audit committees, ${ }^{1}$ and in the United States, insider-dominated boards have been rare for years. ${ }^{2}$ Disinterested $^{3}$ directors have, following the takeover boom in the 1980s, become increasingly important in related state-level litigation, and the modest role for independent directors contemplated in the listing rules of the NYSE has given way, in the wake of Enron and other corporate scandals, to a requirement that independent directors constitute a board majority in domestic companies ${ }^{4}$ as well as federal mandates for listed companies under the SarbanesOxley Act (SOA). ${ }^{5}$

A series of corporate scandals in Britain led to the Cadbury Report and subsequent similar reports and studies, all of which recommended a greater role for outside and independent directors, ${ }^{6}$ and in the last decade Japan has undertaken several corporate law

${ }^{1}$ See infra note 45 and accompanying text.

${ }^{2}$ See Sanjai Bhagat \& Bernard Black, The Uncertain Relationship Between Board Composition and Firm Performance, 54 Bus. LAW. 921, 921 (1999) ("In the 1960s most [large American companies] had a majority of inside directors; today, almost all have a majority of outside directors and most have a majority of 'independent' directors."). As of 2001, approximately $75 \%$ of NYSE-listed companies already had such majorities. See Joann S. Lublin, NYSE Considers Rules to Boost Power of Boards - Fostering the Independence Of Directors Could Improve Governance, Advisers Say, WALL ST. J., June 3, 2002, at A2 (citing report by Investor Responsibility Research Center). In a 2003 survey of its 150 members, the Business Roundtable, an organization of large American corporations, found that $80 \%$ had boards that were at least $75 \%$ independent, and that $90 \%$ had boards that were at least two-thirds independent. See Press Release, Business Round Table, The Business Roundtable Releases Corporate Governance Survey (July 15, 2003), available at http://www.brt.org/press.cfm/970. Another study finds that in the same year, the average percentage of independent directors (as defined by the data source, the Investor Responsibility Research Center) on boards of a broad sample of companies was $68.84 \%$. See Vidhi Chhaochharia and Yaniv Grinstein, The Transformation of US Corporate Boards: 1997-2003 (May, 2004), at 18, available at http://ssrn.com/abstract=556270.

${ }^{3}$ I discuss the difference between disinterested, independent, and outside directors below in Part II.

${ }^{4}$ See New York Stock EXChange, Listed COMPANy MANUAL SEC. 303A.01 (2003), available at http://www.nyse.com/listed [hereinafter LISTED COMPANY MANUAL]. In 2002, in the wake of widely-publicized failures of corporate oversight, the SEC Chairman issued a public statement requesting that the New York Stock Exchange (NYSE) and the National Association of Securities Dealers (NASD) to review and modify corporate governance standards. Securities and Exhange Commission, Release No. 34-48745, NASD and NYSE Rulemaking: Relating to Corporate Governance (Nov. 4, 2003) (discussing the history of the new NYSE rules and citing Commission Press Release No. 2002-23 (Feb. 13, 2002)). In response, the NYSE generated corporate governance reform proposals now included in Section 303 of the Listed Company Manual. See id.

${ }^{5}$ See infra notes 43 to 44 and accompanying text.

${ }^{6}$ See infra notes 73 to 77 and 85 to 87 and accompanying text. As of 2001, outside directors were a board majority in 53\% of companies on the London Stock Exchange. See CORPORATE GOVERNANCE 2001 (PIRC ed., Dec. 2001), cited in MOTOMI HASHIMOTO, COMMERCIAL CODE REVISIONS: PROMOTING THE EVOlution OF JAPANESE COMPANIES 14 (Nomura Research Institute, NRI Papers, No. 48, May 1, 2002). In 2004, however, Pensions Investment Research Consultants reported a board majority of independent directors in well under $15 \%$ of LSE-listed companies. 
reforms designed to enhance the role of directors and auditors not affiliated with management. ${ }^{7}$ Even China has joined this trend: in August, 2001, the China Securities Regulatory Commission (CSRC) issued a rule requiring that at least one third of the directors of listed companies be independent directors by the middle of $2003 .^{8}$

Board independence does not, of course, guarantee corporate success. As one commentator has noted,

Board independence has done little to prevent past mismanagement and fraud. For example, thirty years ago the SEC cast much of the blame for the collapse of the Penn Central Company on the passive nonmanagement directors. No corporate boards could be much more independent than those of Amtrak, which have managed that company into chronic failure and government dependence. Enron had a fully functional audit committee operating under the SEC's expanded rules on audit committee disclosure. ${ }^{9}$

While anecdotal examples of failure do not prove the absence of success, more to the point are the results of several studies of the effect of independent directors on corporate performance in the United States. The overall weight of their findings is that there is no solid evidence suggesting they improve it. ${ }^{10}$ Some studies have even found a negative correlation

Pensions Investment Research Consultants Ltd. (PIRC), Presentation of Corporate Governance Annual Review 2004 (Nov. 18, 2004), available at www. pirc.com.

${ }^{7}$ See notes 88 to 96 infra and accompanying text.

${ }^{8}$ See China Securities Regulatory Commission, Guanyu zai shangshi gongsi jianli duli dongshi zhidu de zhidao yijian [Guidance Opinion on the Establishment of an Independent Director System in Listed Companies] Section 1(1), issued August 16, 2001 [hereinafter Independent Director Opinion]; see generally Donald C. Clarke, The Independent Director in Chinese Corporate Governance, __ DEL. J. CORP. L. _ (2006).

${ }^{9}$ Larry E. Ribstein, Market vs. Regulatory Responses to Corporate Fraud: A Critique of the Sarbanes-Oxley Act of 2002, 28 J. CORP. L. 1, 27 (2002) (footnotes omitted). It is particularly noteworthy that Enron's audit committee "was headed by a widely respected accounting professor and included another respected academic." Paul M. Healy \& Krishna G. Palepu, Governance and Intermediation Problems in Capital Markets: Evidence from the Fall of Enron (Harvard NOM Working Paper No. 02-27, Aug. 15, 2002), available at http://ssrn.com/abstract=325440.

${ }^{10}$ As this is not the place to review the literature comprehensively, see generally Dan R. Dalton et al., Meta-Analytic Reviews of Board Composition, Leadership Structure, and Financial Performance, 19 StRategic MgMt J. 269 (1998); Jill E. Fisch, The New Federal Regulation of Corporate Governance, 28 HARV. J.L. \& PUB. POL'Y 39 (2004); Benjamin E. Hermalin \& Michael S. Weisbach, Boards of Directors as an Endogenously Determined Institution: A Survey of the Economic Literature, FED. RES. BANK N.Y. ECON. POL'Y REV., Apr. 2003, at 7; Laura Lin, The Effectiveness Of Outside Directors As A Corporate Governance Mechanism: Theories And Evidence, $90 \mathrm{NW}$ U. L. REV. 898 (1996); STEPHEN M. BAINBRIDGE, A CRITIQUE OF THE NYSE'S DIRECTOR INDEPENDENCE LISTING STANDARDS (UCLA School of Law, Research Paper No. 02-15, 2002), at http://www.ssrn.com/abstract_id=317121; and Sanjai Bhagat \& Bernard Black, The Non-Correlation Between Board Independence and Long-Term Firm Performance, 27 J. CORP. L. 231 (2002). One study suggesting that outside directors do add value is Kenneth A. Borokhovich et al., Outside Directors and CEO Selection, 31 J. FIN. \& QUANT. ANAL. 337 (1996), a study of CEO successions at 588 large public firms between 1970 and 1988. Dahya and McConnell also found a positive stock price reaction to the increase in outside directors in British companies following the issuance of the Cadbury Report. See Jay Dahya \& John J. McConnell, Outside Directors and Corporate Board Decisions: A Natural Experiment (Nov. 29, 2001), available at http://ssrn.com/abstract $=354380$. Note that these studies are not necessarily all about the same thing. Studies of directors who meet a criterion of outsideness do not, strictly speaking, tell us about directors who meet a criterion of 
between board independence and corporate performance. ${ }^{11}$ A recent comprehensive study by Bhagat and Black ${ }^{12}$ reviews other studies as well as with their own research and finds, among other things, that here is no evidence that greater board independence leads to better firm performance. Poor performance is correlated with subsequent greater independence, but there no evidence that this strategy works to improve performance. While independent directors with significant stock positions may add value, others do not. Indeed, Bhagat and Black find that having insiders on the board can add value. ${ }^{13}$

A study by April Klein ${ }^{14}$ finds that the audit, nomination, and compensation committees, traditionally dominated by outsiders, have little if any effect on firm performance regardless of how they are staffed. Indeed, in direct contrast to conventional wisdom, Klein found a positive correlation between firm performance and the presence of insiders on board finance and investment committees. Evans and Evans for their part found that the presence of independent directors on the board or on compensation committees had no effect on CEO pay levels. ${ }^{15}$

Despite the surprisingly shaky support in empirical research for the value of independent directors, their desirability seems to be taken for granted in policy-making circles. ${ }^{16}$ Yet important elements of the concept of and rationale for independent directors remain curiously obscure and unexamined. As a result, the empirical findings we do have may be misapplied, and judicial gap-filling may be harder than imagined when legislative intent cannot be divined or is contradictory.

This article attempts to unpack the concept broadly understood by the term "independent director" and to distinguish among its various concrete manifestations. I argue that these manifestations serve different purposes and should not be confused one with the

independence, since the latter group excludes those (and those who represent companies) doing extensive business with the company in question, whereas the former group does not.

${ }^{11}$ See Anup Agrawal \& Charles R. Knoeber, Firm Performance and Mechanisms to Control Agency Problems Between Managers and Shareholders, 31 J. Fin. \& QuANTITATIVE ANALYsis 377 (1996); Catherine M. Daily \& Dan R. Dalton, Board of Directors Leadership and Structure: Control and Performance Implications, 17 ENTREPRENEURSHIP: THEORY AND PRACTICE (Spring 1993) 65.

${ }^{12}$ Bhagat \& Black, supra note 10.

${ }^{13}$ This finding is also supported by Barry D. Baysinger \& Henry N. Butler, Revolution vs. Evolution in Corporate Law: The ALI's Project and the Independent Director, 52 GEO. WASH. L. REV. 557 (1984).

${ }^{14}$ April Klein, Firm Performance and Board Committee Structure, 41 J.L. \& ECON. 275

${ }^{15}$ See Robert Evans \& John Evans, The Influence of Non-Executive Director Control and Rewards on CEO Remuneration: Australian Evidence (EFMA 2002 London Meetings, Working Paper Series, Mar. 12, 2001), available at http://ssrn.com/abstract=263050. Interestingly, the authors did find a link between compensation structures for non-executive directors (as they defined them) and CEO pay. Where such directors have equity stakes, CEO pay tends to be lower. Where they do not, CEO pay tends to increase with director pay.

${ }^{16}$ See, e.g., E. Norman Veasey, The Defining Tension in Corporate Governance in America, 52 BUS. LAW. 393, 402 (1997) (asserting the desirability of a board majority of independent directors while acknowledging lack of empirical support for their value). Veasey is the Chief Justice of the Delaware Supreme Court. 
other. ${ }^{17}$ I also argue that the whole purpose of having independent directors is surprisingly undertheorized, leading to inconsistent rules, in particular regarding the effect of director shareholding, both across countries and within the United States.

\section{THE NON-MANAGEMENT DiRECTOR}

\section{A. The Non-Management Director as a General Concept}

In order to canvass various conceptions of the independent director, we must first seek a more general term, for not all jurisdictions place a great deal of importance on directors who might plausibly be called "independent." Different jurisdictions and corporate governance norms speak variously of directors who are "non-interested,"18 "independent,"19 "outside," 20 "non-executive," 21 "non-employee," 22 and "disinterested." ${ }^{23}$ Each of these terms is defined differently and implies a different role for the director it describes, yet they are frequently discussed together as if they were all describing the same thing, ${ }^{24}$ and conclusions about directors of one type are applied to directors of another. ${ }^{25}$

Miwa and Ramseyer, for example, use data on outside directors in Japan to refute what they take to be the conventional wisdom about the role of independent directors. ${ }^{26}$ For

\footnotetext{
${ }^{17}$ It might be thought that this is a no-brainer. As I shall show, however, confusion does in fact exist.

${ }^{18}$ See Investment Company Act (ICA), codified in relevant part at 15 U.S.C. § 80a-2 (2000).

${ }^{19}$ See Securities Exchange Act of 1934 (SEA) § 10A (codified at 15. U.S.C. § 78f(m)(3)(B)
} (2000)). The provision in question comes from Section 301 of the Sarbanes-Oxley Act of 2002 (SOA).

${ }^{20}$ See Shōhō [Commercial Code], Japan, Art. 188(2)(7.2) (2002) (using the term shagai torishimariyaku - literally, "director from outside the company").

${ }^{21}$ See FinANCIAL REPORTING COUNCIL, LONDON STOCK EXCHANGE, REPORT OF THE COMMITTEE ON THE FinANCIAL ASPECTS OF CORPORATE GOVERNANCE \ 4.1 (Gee \& Co., Ltd. 1992), available at http://www.ecgi.org/codes/code.php?code_id=132 [hereinafter CADBURY REPORT].

${ }^{22}$ See Rule 16b-3 under the Securities Exchange Act promulgated by the Securities and Exchange Commission (SEC).

${ }^{23}$ See, e.g., Del. Code ANN. tit. 8 § 144 (2001); Model Bus. CORP. ACT $\S 8.31$.

${ }^{24}$ See, for example, Daniele Marchesani, The Concept of Autonomy and the Independent Director of Public Corporations, 2 BERKELEY BUS. L.J. 315, 321-25 (2005), who discusses "[t]he importance of Independent Directors to the monitoring model of the board" in state jurisprudence, federal legislation, SEC regulations, and stock exchange listing rules. My claim is that there is no single concept of independent director and no single model of what they should do that applies across all the stated fields.

${ }^{25}$ Two prominent Delaware judges, William Chandler and Leo Strine, specifically warn against the danger in adjudication of confusing independence (or the lack of it) with disinterestedness (or the lack of it). See William B. Chandler \& Leo E. Strine, Jr., The New Federalism of the American Corporate Governance System: Preliminary Reflections of Two Residents of One Small State (New York University Center for Law and Business, Working Paper No. CLB 03-01, Feb. 26, 2003), available at $\mathrm{http}: / /$ papers.ssrn.com/abstract $=367720$.

${ }^{26}$ See Yoshiro Miwa \& J. Mark Ramseyer, Who Appoints Them? What Do They Do? Evidence on Outside Directors from Japan (Harvard Univ., John M. Olin Center for Law, Economics and Business, Discussion Paper No. 374, July 2002), available at http://papers.ssrn.com/abstract=326460. 
statistical convenience, however, they follow what they say is the Japanese custom of defining as "outsider" anyone who has a past or concurrent career outside the firm. This would include, for example, partners at law firms whose major client was the firm in question, who would not qualify under most definitions of "independent." Indeed, they explicitly note that the vast majority of outside directors take such directorships as full-time jobs with the firm on whose board they sit. The conventional wisdom about independent directors may indeed be wrong, but no conclusion derived from a study of this kind of outside director can rigorously demonstrate it. $^{27}$

The generic term I shall use here is "non-management" director (NMD), because it captures the one element all the above terms have in common: the director in question is not a member of the current senior management team. ${ }^{28}$ This negative feature is, however, consistent with several different positive features, some of which are mutually inconsistent, and each of which contemplates a different conception of the role of the non-management director.

Before canvassing these conceptions, it will be useful to set forth some general ideas about the possible functions of NMDs in a corporate governance system. ${ }^{29}$ The particular conceptions of different jurisdictions can then be analysed in terms of which function or functions they seem to value, and whether those functions are in fact likely to be fulfilled.

The role of NMD can be analyzed according to whether the NMD is perceived as a substitute for external regulation or as an implementer of it. In American corporate law, for example, the NMD primarily functions as a substitute for external regulation. Courts and legislatures are wary of becoming too involved with the business decisions of corporate management. Thus, even the apparently fundamental and unobjectionable idea that transactions between a corporation and a director should be on terms that are fair to the corporation is not imposed on corporations as a substantive rule of law in Delaware or in the Model Business Corporation Act (MBCA) if the corporation's board has disinterested directors and a majority of them have, after full disclosure, approved the transaction. ${ }^{30}$

There are several ways in which NMDs might improve corporate functioning from the inside. As noted above, one role for NMDs is as a monitor of related-party transactions,

${ }^{27}$ The definition of "outside director" (shagai torishimariyaku) in Japanese law is somewhat stricter than the Miwa-Ramseyer definition, and the distinction between outside directors and independent directors is well understood. See infra note 94; see also Yamada Okashi, Shagai torishimariyaku to dokuritsu torishimariyaku [The outside director and the independent director], Part I, 2005 Hōritsu JiHŌ [Legal Times], No. 1, at __; Part II, 2005 HōRITSU JiHō [Legal Times], No. 2, at

${ }^{28}$ This is, of course, what is usually meant by "non-executive" director. On the other hand, some people say "non-executive" when they really mean "independent" or "outside." I am deliberately creating a new term here so that what I mean by it can be kept clear.

${ }^{29}$ On the role of boards generally, see Stephen M. Bainbridge, Why a Board? Group Decisionmaking in Corporate Governance, 55 VAND. L. REV. 1, 8 (2002); Lynne L. Dallas, The Multiple Roles of Corporate Boards of Directors, 40 SAN DIEGO L. REV. 781, 801-809 (2003); Lynne L. Dallas, The Relational Board: Three Theories of Corporate Boards of Directors, 22 J. CORP. L. 1 (1996); Jonathan L. Johnson et al., Boards of Directors: A Review and Research Agenda, 22 J. MGMT 409, 411 (1996); Donald J. Langevoort, The Human Nature of Corporate Boards: Law, Norms, and the Unintended Consequence of Independence and Accountability, 89 GEO. L.J. 797, 801-805 (2001).

${ }^{30}$ See the discussion below at text accompanying notes 100 to 104 . 
where there could be a conflict of interest. Note that if NMDs are to perform this function effectively, their qualifications cannot be abstractly defined before the fact. A transactionbased approach that looks at the director's interest in a particular transaction is required; otherwise a director wholly independent of management, for example, would be deemed fit to vote on a transaction between the company and herself.

Another school of thought sees NMDs as protecting small shareholders against large shareholders, who use their voting power to select directors and managers who will do their bidding at the expense of the powerless minority. ${ }^{31}$ But given that corporate law is generally designed to give the largest shareholders the largest voice in choosing directors, it is hard to see how directors representing minority shareholders could be elected to the board in the first place unless the basic principles of director selection were changed. Cumulative voting is a possible solution, but this system will elect directors representing at best a concentrated minority, not a dispersed minority, and even then such directors will be in a minority on the board and can always be outvoted.

Obviously, even one isolated director can provide a degree of protection to minority shareholders by publicizing, or threatening to publicize, majority shareholder abuses of which he becomes aware. It is not clear, however, if this is the kind of strong protection envisaged by advocates of the independent director system.

A third internal function for NMDs frequently mentioned is that of brain trust or consultant. ${ }^{32}$ But in many cases the company might well do better to hire consultants and other experts for advice, instead of having them sit on the board until such time as they might be needed. What are the incentives of such directors to devote time and resources to their advisory task? If outside or independent directors who give valuable advice are compensated any differently from directors who do not, then they may cease to meet the definition of outside or independent director. Furthermore, if giving advice is the appropriate role, why do the directors need to satisfy any criterion of independence at all? ${ }^{33}$

${ }^{31}$ This school of thought is particularly prominent in the literature about independent directors in China. See, e.g., Gu Gongyun, Gongsi Fa xiugai ying jiejue de ruogan shiji wenti [Several Practical Problems that Should Be Solved in a Revision of the Company Law], in GongSI FA XIUGAI ZONGHENG TAN [An All-Around Discussion of Revision of the Company Law], at 57, 60 (Guo Feng $\&$ Wang Jian ed., Falü Chubanshe 2000); Richard McGregor, China Plans New Market Rules, FIN. TIMES, Apr. 19, 2001, at 25 (reporting remarks by Laura Cha (Shi Meilun), deputy head of the China Securities Regulatory Commission, about "egregious" behavior by controlling shareholders of Chinese listed companies).

${ }^{32}$ See the discussion of outside directors in Part II.B.2, infra.

${ }^{33}$ Although outside directors are common in Japan, the Revised Corporate Governance Principles of the Japan Corporate Governance Forum specifically view their advisory function as secondary:

In Japan, although there is a strong bias towards requesting managerial advice from outside directors, this phenomenon is, at best, a secondary function, and managers and employees alike in Japan need to be reminded that the primary role of outside directors is that of governance.

JAPAN CORPORATE GOVERNANCE FORUM, REVISED CORPORATE GOVERNANCE PRINCIPLES (Oct., 26, 2001), available at http://www.ecgi.org/codes/code.php?code_id=70. Miwa and Ramseyer, however, cast doubt on the primacy of the governance role at least as a descriptive matter. Noting that outside directors often come from companies and institutions that are customers of the company in question, they hypothesize that outside directors are useful to Japanese companies because of their understanding of customer needs. Such directors need not be in any way independent of management 
In the United States, the NMD has traditionally been seen as the solution to the problem of managerial domination of the board. ${ }^{34}$ This model assumes the existence of the paradigmatic Berle and Means corporation, where powerful managers exploit dispersed and rationally apathetic shareholders. ${ }^{35}$ This explains why, as far as American law is concerned, it is generally considered a good thing, not a bad thing, for NMDs to own stock in the company on whose board they sit. ${ }^{36}$ When the law's concern includes dominant shareholder exploitation of minority shareholders, then it makes sense to give more prominence to the notion of the disinterested director: disinterested not in the abstract, but with respect to a particular challenged transaction.

One could also imagine NMDs as implementers of external regulation. In such a case, the relevant standard of behavior would be set externally, not by the NMDs themselves, and they would be expected to help implement those standards. This could be done in a number of ways: through exercising their voting power on the board to induce the company to act in

in order to fulfill this function, and indeed such directors apparently assume full-time employment as company directors - that is, they resign any other positions - upon taking their position. See Miwa \& Ramseyer, supra note 26.

${ }^{34}$ See, e.g., Baysinger \& Butler, supra note 13, at 563-64 (1984). Here the NMD does more than police traditional conflict-of-interest transactions. The managerial conflicts of interest of concern here are those that Eisenberg has called "positional conflicts of interest": the hard-to-monitor tendency of top managers to take steps well within their managerial prerogative, such as acquisitions or diversification, that benefit themselves at the expense of the shareholders. See Melvin Aron Eisenberg, The Architecture of American Corporate Law: Facilitation and Regulation, 2 BERKELEY BuS. L.J. 169, 170-71 (2005).

${ }^{35}$ See Adolph A. Berle \& Gardiner C. MeAns, THE Modern Corporation AND PRIVATE PROPERTY (Macmillan 1933). As has been shown above, China has few, if any, such listed corporations. Indeed, it is not clear how dominant they are even in the United States. See, e.g., Randall Morck et al., Management Ownership and Market Valuation: An Empirical Analysis, 20 J. FIN. ECON. 293 (1988) (finding a modest concentration of ownership even among the largest United States firms); R. La Porta et al., Law and Finance, 106 J. POL. ECON. 1113, 1146 (1998) (finding that ownership of the three largest shareholders in the ten most valuable United States companies has a mean average of $20 \%$ and a median of $12 \%$ ).

${ }^{36}$ See, for example, Unitrin, Inc. v. American General Corp., 651 A.2d 1361, 1380-81 (Del. 1995), in which the Delaware Supreme Court granted extra deference to the views of outside directors who held "substantial equity stakes" in a corporation that was the target of a takeover bid, presuming that they would "act in their own best economic interests" as stockholders and not out of a desire to entrench existing management. See also R. Franklin Balotti et al., Equity Ownership and the Duty of Care: Convergence, Revolution, or Evolution, 55 BUs. LAW. 661 (2000) (reviewing empirical evidence in support of link between substantial equity ownership and improved director monitoring and decision making, and arguing in favor of presumption of due care for directors with substantial equity ownership); Chandler \& Strine, supra note 25 (favoring stock ownership by independent directors and questioning the suspicious approach of the SOA); J. Travis Laster, Exorcizing The Omnipresent Specter: The Impact Of Substantial Equity Ownership By Outside Directors On Unocal Analysis, 55 BUS. LAW. 109 (1999) (discussing a series of cases in which Delaware courts have given deference to decisions by directors on the grounds that their substantial equity ownership aligned their interests with those of other shareholders).

In Stroud v. Grace, No. 10,719 (Del. Ch. Nov. 1, 1990), 16 DEL. J. CoRP. L. 1588 (1991), the Delaware Chancery Court addressed a party's argument that a corporate charter provision requiring independent directors on the board but forbidding them from owning stock should be invalidated. The court found the provision to be unusual, but not unlawful. The prohibition in that case stemmed from the particular needs of the dominant shareholder in a family-controlled close corporation. 
compliance with the standards, through using their access to information to alert the authorities to non-compliance, or through using their access to information to certify compliance.

Each of these methods, however, poses difficulties. If one is to rely on NMDs to exercise their voting power in favor of compliance with external standards, then there needs to be some reason for believing that NMDs will be more likely to do so than non-NMDs. Both kinds of directors can be subject to sanctions for voting to violate clear legal obligations. If the purpose is to encourage corporations to act in accordance with principles that do not constitute legal obligations (for example, "maximize local employment"), then it is unlikely that NMDs elected by, and accountable to, profit-maximizing shareholders will produce this result. A director serving the "public interest" should arguably be independent of everyone - dominant shareholders, management, and indeed all those who have an interest in the company - and follow only the dictates of her conscience. Assuming accountability to be a good thing, however, it is hard to see how such a director could properly be made accountable. In the real world, of course, any director without security of tenure will, in the absence of counterincentives and assuming that the position is desirable, tend to be accountable to whoever was responsible for appointing her.

If the state relies on NMDs to use their access to information to alert it to corporate non-compliance with legal standards, then once again one runs up against the problem of how to select directors who will internalize this duty. Moreover, directors whose job it is to inform on the company will find their access to information considerably decreased. Again, it is perfectly conceivable to have a rule that requires directors and others with knowledge of certain types of violations to report them to the authorities, ${ }^{37}$ but there does not seem to be any reason to distinguish NMDs from non-NMDs in this respect.

Finally, it is possible to use NMDs to certify that certain standards have been complied with-for example, that the annual report is accurate, or that the balance sheets have been prepared in accordance with proper accounting standards. In the United States, this job is generally left to independent professionals, and their duty of care is enforced, among other ways, by allowing persons to rely on the certification and to sue if that reliance results in damages. There is no particular reason why NMDs could not perform this function, but there is no particular reason why they should. If NMDs are required to back up their certification with their personal wealth, few may be willing to take on the job. If they are not, then they have little incentive to be responsible. A separate firm that specializes in the information in question - an accounting firm or a law firm, for example - can get access to the same information if the company is willing to grant it (and it would have to do so), and can better bear the risk of the occasional error leading to liability. Moreover, certification of information by a large organization with a reputation to consider is more likely to be reassuring to users of that information than certification by an unknown person of unknown resources. ${ }^{38}$

${ }^{37}$ See, for example, 12 C.F.R. 208.62 (2005), which requires United States banks to file reports of suspected criminal activity with the Federal Reserve Bank and subjects directors and officers, among others, to disciplinary action if the bank fails to do so.

${ }^{38}$ But see John C. Coffee, Jr., Understanding Enron: It's About the Gatekeepers, Stupid (Columbia Law \& Economics Working Paper No. 207, July 30, 2002), available at $\mathrm{http}: / / \mathrm{ssrn} . \mathrm{com} / \mathrm{abstract}=325240$ (arguing that reputation is not as effective a policing mechanism as is commonly assumed). 


\section{B. Variations on the Theme}

Differing conceptions of the NMD's role are not (at least usually) mere abstract ideas. Different conceptions imply different structures within which such directors are to fulfill their contemplated role. The following discussion will not, therefore, simply canvass different definitions of the NMD.$^{39}$ It will also bring out how those different definitions relate to the different functions of the director.

\section{The "Independent" Director}

As the independent director is the most commonly discussed form of the nonmanagement director, it is simplest to start with this concept and then discuss how the other concepts differ from it. Here we run immediately into a problem: the proper definition of "independent director" depends on the role envisaged for him. Shall we examine the different roles, and therefore definitions, that have been proposed for "independent directors," or shall we single out one role, with its corresponding definition, no matter what the name attached to it?

For the sake of clarity, I propose to take the latter approach. There is indeed disagreement over the proper role for non-management directors, sometimes phrased as disagreement over the proper role for independent directors. But as disagreements over role have implications for the particular desired conception of non-management director, they can be coherently discussed within the framework offered here.

A major theme in corporate governance writing is the need for non-management directors on the board to serve as a check on management in the interests of shareholders. In other words, non-management directors are there to help shareholders solve the agency problem. If such directors are to monitor management effectively, they must be independent of management. From this contemplated role stems the typical definition of independent director: one who has no need or inclination to stay in the good graces of management, and who will be able to speak out, inside and outside the boardroom, in the face of management misdeeds in order to protect the interests of shareholders.

A competing conception of the director who is independent of management holds that the director's duty is to mediate among interests of a number of different groups, not just shareholders, and indeed sometimes to act against the interests of shareholders in order to protect, for example, employees. ${ }^{40}$ The latter view of the role of the independent director-

${ }^{39}$ For a convenient table showing different conceptions of what I call the NMD, see CALIFornia PUblic EMPloyees' RetiREMENT System (CAlPERS), Corporate Governance Core Principles and Guidelines: The United States, Appendix B-2 ("Variations on a Theme'Independent Director"') (1998), available at http://www.calpersgovernance.org/principles/domestic/us/page01.asp.

${ }^{40}$ For a discussion of these competing concepts, see Victor Brudney, The Independent Director-Heavenly City or Potemkin Village? 95 HARV. L. REV. 597, 602 (1982). The "shareholder versus stakeholder" debate has been going on for over seventy years. See Adolph A. Berle, Corporate Powers as Powers in Trust, 45 HARV. L. REV. 1049 (1932) (arguing that directors should serve shareholder interests) and E. Merrick Dodd, For Whom Are Corporate Managers Trustees?, 45 HARV. L. REV. 1145 (1932) (arguing that directors should serve other groups including employees, managers, and society in general). For recent contributions, see William T. Allen, Our Schizophrenic Conception of the Business Corporation, 14 CARDOzO L. REV. 261 (1992); William T. Allen et al., The Great Takeover Debate: A Meditation on Bridging the Conceptual Divide, 69 U. CHI. L. REV. 1067 (2002) (discussing the debate); Stephen M. Bainbridge, Director Primacy: The Means and Ends of Corporate Governance, 97 NW. U. L. REV. 547 (2003) (arguing for shareholder primacy); Margaret 
one who is independent of profit-seeking shareholders as well as independent of management - has not, however, found fertile soil in American corporate law scholarship or practice. The dominant view has been that directors who are responsible to many constituencies are in effect responsible to none, and that while many of those who deal with the firm, such as customers, workers, and suppliers, can protect themselves through contract and the threat of terminating their association with the firm, the shareholders are uniquely unable to do so because their investment is sunk and cannot be withdrawn. ${ }^{41}$

Both conceptions share the idea that the directors expected to perform their designated function cannot do so unless they are systematically independent of management. This idea is familiar to corporate law practitioners and scholars in the United States, but interestingly, its reach is limited almost exclusively to federal law as applied to corporations whose stock is listed on a national exchange. ${ }^{42}$ Section 301 of the SOA requires ${ }^{43}$ that all members of a listed company's audit committee be independent directors, and states:

In order to be considered to be independent for purposes of this paragraph, a member of an audit committee of an issuer may not, other than in his or her capacity as a

M. Blair \& Lynn A. Stout, A Team Production Theory of Corporate Law, 85 VA. L. REV. 247 (1999) (arguing that directors should take non-shareholder interests into account).

${ }^{41}$ See, e.g., HENRY HANSMANN, THE OWNERSHIP OF ENTERPRISE 56 (Harvard Univ. Press 1996); Henry Hansmann \& Reinier Kraakman, The End of History for Corporate Law, 89 GEO. L.J. 439, 442 (2001). Gilson and Kraakman go beyond emphasizing the independence of the nonmanagement director in order to stress the desirability of her lack of independence from shareholders: "[W]hile most recent efforts addressing the governance role of the board have urged increasing the independence of outside directors from management, we advocate increasing the dependence of outside directors on shareholders. In our view, corporate boards need directors who are not merely independent, but who are accountable as well." Ronald J. Gilson \& Reinier Kraakman, Reinventing the Outside Director: An Agenda for Institutional Investors, 43 STAN. L. REV. 863, 865 (1991). A recent World Bank publication makes the same point. See STOYAN TENEV \& CHUNLIN ZHANG, CORPORATE GOVERNANCE AND ENTERPRISE REFORM IN CHINA (World Bank and the International Finance Corporation 2002). The Higgs Report points up the need for such accountability: a majority (52\%) of the non-executive directors surveyed never discussed company business with investors, and only one in five non-executive directors in FTSE 100 companies did so at least once a year. See DEREK HigGS, REVIEW OF THE ROLE AND EFFECTIVENESS OF NON-EXECUTIVE DiRECTORS $\ 15.5$ (The Stationery Office 2003), available at http://www.dti.gov.uk/cld/non_exec_review/. This seems to be taking independence a bit too far.

${ }^{42}$ I deal below with state corporate law and its different concept of "disinterested director." The Investment Company Act, a federal statute, also contains what is essentially a requirement for independent directors in investment companies, whether or not they happen to be listed. The relevant section is discussed briefly below. Finally, because this paper is not intended to be an exhaustive discussion of post-SOA reforms in American corporate governance, I discuss such reforms in general terms only and do not note the numerous exceptions and qualifications to the general rules set forth here.

${ }^{43}$ Strictly speaking, the SOA requires that the SEC adopt rules requiring national securities exchanges and national securities associations to prohibit the listing of the securities of any issuer that does not comply with the standards for independence of audit committee members set forth in Section 301. The SEC adopted such rules on April 1, 2003. See Press Release 2003-43, Securities and Exchange Commission, SEC Requires Exchange Listing Standards for Audit Committees (Apr. 1, 2003), at www.sec.gov/news/press/2003-43.htm. See generally Standards Relating to Listed Company Audit Committees, Exchange Act (as added by Sarbanes-Oxley Act of $2002 \S 301$ ) Release Nos. 338220, 34-47654, 68 Fed. Reg. 18788 (Apr. 16, 2003), available at http://www.sec.gov/rules/final/338220.htm. 
member of the audit committee, the board of directors, or any other board committee-

(i) accept any consulting, advisory, or other compensatory fee from the issuer; or

(ii) be an affiliated person of the issuer or any subsidiary thereof. ${ }^{44}$

The SOA has no role for independent directors other than as audit committee members, but requires the audit committee to have quite substantial powers, including the sole authority to hire, oversee, compensate, and fire the outside auditor. Its definition of independence is quite strict compared with others. The director may not, for example, accept any compensation from the issuer other than for his services as a director.

The NYSE's former (that is, prior to SOA-associated reforms) and current rules on independent directors make an informative contrast. Under the former rules, independent directors were required only for audit committees, and were those who had "no relationship to the company that may interfere with the exercise of their independence from management and the company." ${ }^{45}$ Independence was further foreclosed if the director or a family member had one of a number of specific relationships with the company, ${ }^{46}$ including a business relationship except where the company's board affirmatively determined that the business relationship would not interfere with the director's exercise of independent judgment.

As can be seen, the NYSE's former rules were more flexible than those of the SOA, allowing the board in many circumstances to waive presumptive bars to independence. Because independent directors are not required to play so important a role - the audit committee had to be composed entirely of independent directors, but it did not need to have the exclusive authority to hire, monitor, and terminate the outside auditor - it was not so critical to maintain a strict distinction between independent and non-independent directors.

In response to the requirements of the SOA, the NYSE adopted rules that mirror the SOA's independence requirements for audit committee members, but that retain some flexibility with respect to other independent directors:

${ }^{44}$ Sarbanes-Oxley Act of $2002 \S 301$ (codified at 15 U.S.C. 78f). Note that "affiliated person" could, in a way perhaps unintended by Congress, include someone who has no ties to management but owns a large block of stock and therefore has, one would think, an extra incentive to monitor management for the benefit of stockholders. "Affiliated person" is defined for purposes of this section by new Rule 10A-3 under the SEA (17 CFR 240.10A-3) and tracks (more or less) the definition of "insider" under Section 16 of the SEA (17 U.S.C. 78p). "Affiliate" is defined in terms of control, and control is defined in part in terms of stock ownership: ownership of less than $10 \%$ is defined, in a safe harbor, as not constituting affiliation, but ownership of at least $10 \%$ could be considered an affiliation sufficient to negate a finding of independence. This issue is further discussed below at note 57 and accompanying text.

${ }^{45}$ NeW York Stock Exchange, Listed Company ManUaL $§ 303.01$ (2002).

${ }^{46}$ Specifically, independence was foreclosed if the director (a) had been employed by the issuer or its affiliates in the past three years, (b) was an immediate family member of a person employed as an executive officer of the issuer or its affiliates in the last three years, (c) was employed as an executive of another company where any of the issuer's executives sat on the compensation committee, (d) had a direct business relationship with, or was a partner, shareholder, or executive officer of an organization that had a direct business relationship with, the issuer, unless the issuer's board made an affirmative determination that the relationship would not interfere with the director's exercise of independent judgment. 
For a director to be deemed "independent," the board must affirmatively determine that the director has no material relationship with the listed company (either directly or as a partner, shareholder or officer of an organization that has a relationship with the company). Companies must disclose these determinations in their annual proxy statements. $^{47}$

Companies may also adopt and disclose categorical standards, making a general disclosure if a director meets those standards. There are certain presumptive bars to independence, such as receiving more than $\$ 100,000$ per year in compensation (other than for serving as a director) from the company, but the board may affirmatively determine that such circumstances do not constitute a bar to independence.

Unlike the SOA, the NYSE rules (except where they mirror SOA requirements) do not contemplate specific mandatory powers for independent directors. In addition to an audit committee, listed companies must have a nominating committee and a compensation committee, each composed solely of independent directors. Unlike the audit committee, however, these committees need not have exclusive power in their respective field, and could be limited simply to making recommendations to the board as a whole.

On the other hand, independent directors must constitute a majority of the board. ${ }^{48}$ The theory behind the NYSE rules seems to be that corporate decision making will be improved if a majority of the board can be structured so that a particular motivation - that of pleasing management - is absent. The rules do not attempt to ensure that a particular motivation is present.

Enforcement of the NYSE's independent director requirement seems to be through the familiar method of disclosure plus liability under federal securities law for false or misleading disclosures. At least once a year in its proxy statements, a listed company must disclose that it has affirmatively determined the requisite number of directors to be independent, or that the requisite number meet disclosed categorical standards. ${ }^{49}$ Provided the board did in fact make the determination in question, however, it is not clear how directors could be made accountable for a determination that was later argued to be wrong due either to genuine error or to bad faith.

${ }^{47}$ LiSTED COMPANY MANUAL, supra note 4 , at $\S 303 \mathrm{~A}$.

${ }^{48}$ The requirement for independent directors is subject to an exception for controlled companies, except with respect to the audit committee. Controlled companies are those in which more than $50 \%$ of the voting power is controlled by a single individual, group, or company.

${ }^{49}$ See LISTED COMPANY MANUAL, supra note 4, at $\S 303 \mathrm{~A}$. If a board does not use categorical standards, it must specifically disclose its basis for determining that any particular relationship of a director with the company is not material such that it would compromise the director's independence. As an alternative, the board may adopt and disclose categorical standards and make a general disclosure that a director meets those standards without having to detail the immaterial relationships between the director and the company. It may also find independent a director who does not meet those standards, but the basis for that finding must be disclosed.

Examples of such categorical standards can easily be found on the World Wide Web. See, for example, Pfizer Corporation, Corporate Governance: Director Qualification Standards, available at http://www.pfizer.com/pfizer/are/mn_investors_corporate_dqs.jsp (last visited Feb. 2, 2006);

Scotiabank, Director Independence Standards, available at http://www.scotiabank.com/cda/content/0,1608,CID8435_LIDen,00.html (last visited Feb. 2, 2006); Xerox Corporation, Independence of the Board, available at http://www.xerox.com/go/xrx/template/009.jsp?view=Feature\&Xcntry=USA\&Xlang=en_US\&ed_na $\mathrm{me}=$ Director_Independence (last visited Feb. 2, 2006). 
The listing rules of the Nasdaq National Market also call for independent directors, but in a way that shows how seemingly minor technical rules can make apparently similar requirements quite different. The rules prior to SOA-associated reforms defined an independent director as "a person other than an officer or employee of the company or its subsidiaries or any other individual having a relationship which, in the opinion of the company's board of directors, would interfere with the exercise of independent judgment in carrying out the responsibilities of a directors." ${ }^{50}$ This general definition was followed by some per se exclusions. They included a director who (a) had been employed by the company or an affiliate in the last three years; (b) had accepted over $\$ 60,000$ in compensation from the company or affiliates in the last year; (c) was a member of the immediate family of anyone employed as an executive by the company or affiliates in the last three years; (d) was a partner, controlling shareholder, or executive of an organization that had, in any of the last three years, received payments totalling the greater of (i) $5 \%$ of the organization's gross revenues for that year, or (ii) $\$ 200,000$; or (e) was employed as an executive of another company where any of the issuer's executives sat on the compensation committee. Note that this definition would consider "independent" a person who received up to $\$ 60,000$ a year as a consultant to the company unless the board made an affirmative finding to the contrary.

National market companies were required to have an audit committee of at least three members, all of whom were to be independent directors (subject to a minor exception). As with the former NYSE rules (but unlike the SOA requirements and the corresponding current NYSE rules), the audit committee was not required to have sole responsibility for hiring and firing the outside auditor. ${ }^{51}$

Under post-SOA reforms to the Nasdaq listing rules, ${ }^{52}$ company boards must have a majority of independent directors. The definition follows that of the former rule, with the following exceptions: (a) the per se rule against acceptance of payments of over $\$ 60,000$ is generally extended to family members of those who receive such payments (unless such family members are non-executive employees), and the look-back period is extended to three years; (b) a three-year look-back period is added to the compensation committee condition, and the bar is extended to directors with family members who were executives at the other company in question; and (c) a per se rule is added barring independent status for directors who within the past three years were, or had family members who were, partners or employees of the company's outside auditor and worked on the company's audit.

As with the pre-SOA rules, anyone not employed by the company and not excluded by the per se rules is automatically deemed independent unless the board makes a specific finding to the contrary. This is significantly different from the NYSE rules, where an affirmative finding of independence is required. To the extent that the enforcement of the standards of independence depends on disclosure, this makes the Nasdaq rules somewhat weaker, because there is less to disclose.

On the other hand, the Nasdaq rules give more power to independent directors than do the NYSE rules. As in NYSE-listed companies, audit committees are to have the exclusive power to hire and fire the outside auditor. Unlike in NYSE-listed companies, however, the compensation of officers is to be decided by a majority of independent directors or by a compensation committee consisting solely of independent directors (subject to minor

\footnotetext{
${ }^{50}$ NASDAQ, NASDAQ MARKETPLACE RULES Sec. 4200(a)(14) (2002).

${ }^{51}$ See id. at Sec. 4350(d).

${ }^{52}$ See Securities Exchange Act Release No. 34-47516, 68 FED. REg. 14451, 14415-56 (Mar. $25,2003)$.
} 
exceptions), and board nominations are to be decided in a similar fashion. Although both NYSE-listed and Nasdaq-listed company boards must have a majority of independent directors, the board as a whole in an NYSE-listed company could override the views of a majority of independent directors in matters of compensation and nomination, whereas the same would not be possible in a Nasdaq-listed company. ${ }^{53}$

While "independence" has generally proven fairly easy to conceptualize, if more difficult to define in precise legislative language, one area in which substantial disagreement exists even in principle is that of the significance to be given to stock ownership by the putatively independent director. Those who see the independent director primarily as a defender of shareholder interests against management will naturally see more share ownership as better, because it will more closely align the interests of the director with the shareholders as against management. ${ }^{54}$ Those who view the independent director as someone whose judgment should be untainted by any financial interest in the company are suspicious of share ownership. ${ }^{55}$

${ }^{53}$ After canvassing the NYSE and Nasdaq rules, not much would be added by an extensive discussion of the American Stock Exchange's (Amex) post-SOA rules, which do not offer startling differences. Briefly, the rules call for a board on which a majority of directors qualify as independent, and the independent directors must meet in executive session (without the other directors) at least once a year. They consider stock ownership to be a good thing, not a bad thing, and exempt controlled companies (to the extent permitted by the SOA) from their purview. See generally AMERICAN STOCK EXCHANGE, AMEX COMPANY GUIDE - PART 8: CORPORATE GOVERNANCE REQUIREMENTS $\S \S 801-9$, available at

http://wallstreet.cch.com/AmericanStockExchangeAMEX/AmexCompanyGuide/PART8/default.asp.

${ }^{54}$ In general, ownership of stock by directors, and by independent directors in particular, appears to be positively correlated with company performance. See Sanjai Bhagat et al., Director Ownership, Corporate Performance, and Management Turnover, 54 BUS. LAW. 885 (May 1999); Eliezer M. Fich \& Anil Shivdasani, The Impact of Stock-Option Compensation for Outside Directors on Firm Value, 78 J. Bus. 2229 (2005); Balotti et al., supra note 36. For a contrary view, see Lawrence D. Brown \& Marcus L. Caylor, Corporate Governance and Firm Performance, at 9 (Dec. 7, 2004), available at $\mathrm{http}: / / \mathrm{ssrn} . c 0 \mathrm{~m} / \mathrm{abstract}=586423$ (finding "no evidence that operating performance or firm valuation is positively related either to stock option expensing or directors receiving some or all of their fees in stock").

${ }^{55}$ China, for example, unambiguously adopts the suspicious approach and disfavors stock ownership by independent directors. See, e.g., Independent Director Opinion, supra note 8, Section 1(1) (forbidding any relationship with a large shareholder that would impair independence); $i d$., Section 3(2) (denying independent status to holder of 1\% of company's shares or one of top ten shareholders or relative of the latter); People's Bank of China, Guanyu gufenzhi shangye yinhang duli dongshi he waibu jianshi zhidu zhiyin [Guidelines on the System of Independent Directors and Outside Supervisors for Commercial Banks Under the Shareholding System] Art. 2, issued and effective June 4, 2002 [hereinafter Commercial Bank Independent Director Guidelines] (denying independent status to holder of $1 \%$ of company's shares or employee of shareholder).

Some commentators appear to take both positions at once. Derek Higgs, in his recent report on non-executive directors commissioned by the British Department of Trade and Industry, agrees in Para. 12.26 that "shares could be helpful in aligning the interests of the director with the long-term interests of shareholders", but opposes in Para. 12.27 the holding of options by directors "because of the risk of undesirable focus on share price rather than underlying company performance". HIGGS, supra note 41. It is not clear why directors who own shares will be less focused on share price than directors who own options, or why shareholders would not want a director to be focused on share price. The notion of a generally knowable distinction between long-term share price and short-term share price is illusory, because the share price at any given time reflects the market's best guess as to the discounted present value of all income (not just income over the short term) that can be earned by 
It is not altogether clear which view Congress took in the SOA. As we have seen, Section 301 of the SOA amends Section $10 \mathrm{~A}$ of the SEA ${ }^{56}$ by providing that an independent director on the audit committee may not be an "affiliated person" of the company. The SOA itself does not define "affiliated person." Congress may have intended simply to apply the definitions of the SEA into which the new language was inserted. Section 3(a)(19) of the SEA states that "affiliated person" in the SEA shall have the meaning given to it by the Investment Company Act (ICA). The ICA for its part defines "affiliated person" in part as anyone owning $5 \%$ or more of the securities of the company. Thus, Congress could be seen as viewing substantial ownership of securities as undesirable in independent directors - even though, ironically, the ICA does not itself see stock ownership as a bar to independence. ${ }^{57}$

The SEC, however, has taken the view (to the best of my knowledge, uncontroversially) that "affiliated person" is a term it may define through its general rulemaking power under Section 3(a) of the SOA, or perhaps through its power under Section 301 of the $\mathrm{SOA}^{58}$ to exempt particular relationships from the general prohibitions. While it has retained the ICA stock ownership threshold for independent directors of investment companies, it has been much friendlier to shareholding by independent directors in other circumstances, and has created an explicit safe harbor for shareholding under $10 \%$. Moreover, it has stated that shareholding of $10 \%$ or more will not automatically be construed to constitute an "affiliation" sufficient to prevent a director from being found "independent."

The two exchanges, for their part, differ from federal law and from each other. The NYSE simply incorporates by reference the requirements of federal law as far as audit committee members are concerned. But where its own requirement for a majority of independent directors is concerned - a requirement not imposed by federal law - it imposes no limits on shareholding whatsoever. Indeed, in proposing its rule change, the NYSE specifically noted the views of commentators that share ownership should be viewed as desirable, and stated that "as the concern is independence from management, the Exchange does not view ownership of even a significant amount of stock, by itself, as a bar to an independence finding." ${ }^{59}$

the share, whether through dividends or ultimate sale, and thus incorporates all long-term share prices to the extent they can be estimated. A director privy to inside information might well have reason to believe that the current share price does not reflect the valuation the market would place on the stock were the information public, but any undesirable incentives created by this information asymmetry do not depend on whether the director holds stock or options. In any case, while recognizing the beneficial effect of share ownership by directors, the Higgs Report views significant share ownership as disqualifying a director from being considered independent. See id. at 37.

${ }^{56}$ Codified at 15 U.S.C. $§ 78(f)$.

${ }^{57}$ The ICA uses the definition of "affiliated person" in its own definition of the term "interested director" (i.e., directors who do not meet the ICA's standards of independence), but specifically exempts those who fall within the definition of "affiliated person" solely by virtue of their stock ownership. See 15 U.S.C. § 80a-2(a)(19)(A) (2000). The definition of "affiliate" in the ICA, therefore, was never intended to make stock ownership by directors a bar to a finding of independence.

${ }^{58}$ SeCurities EXChange Act Sec. 10A(m)(3)(C).

${ }^{59}$ See Notice of Filing of Proposed Rule Change and Amendment No. 1 Thereto by the New York Stock Exchange, Inc., Exchange Act Release No. 34-47672, 68 FED. REG. 19051 (Apr. 11, 2003), available at http://www.sec.gov/rules/sro/34-47672.htm; see also New York Stock Exchange, Section 303A Corporate Governance Rules, Nov. 3, 2004, available at http://www.nyse.com/pdfs/section303A_final_rules.pdf. 
Nasdaq takes a different view. It sets a limit on audit committee director shareholding of the lower of (a) whatever the SEC prescribes under the SOA, and (b) $20 \%$. As we have seen, the SEC has not in fact prescribed any per se upper limit on director shareholding (although it has established a safe harbor of under 10\%). Thus, Nasdaq may end up forbidding what the SEC, which defines affiliation via a concept of control, might allow. Unlike the NYSE, however, Nasdaq did not in its SEC submission ${ }^{60}$ explain its views on the desirability of shareholding by independent directors, so we will not know the reason why this result was thought appropriate.

Although the SEC's rulemaking has not been actively hostile to shareholding by independent directors, it is important to note a fundamental difference in approach between the SEC and both the exchanges in their proposed rules. Both the exchanges require company boards to have a majority of independent directors except when the company is a "controlled company"-i.e., when a single person, group, or company controls more than $50 \%$ of the voting power. ${ }^{61}$ In other words, they see independent directors as a protection for shareholders specifically against management, not against other shareholders. A shareholder who controls a company does not need an external rulemaker to protect him from a management team that he himself has the power to appoint. Minority shareholders may well need protection from controlling shareholders, but the exchanges are apparently willing to leave this task to other bodies of law, such as federal securities law requiring disclosures and state corporate law mandating certain fiduciary duties.

The SEC's approach, however, is different. As we have seen, an "affiliated person" cannot be "independent," and the SEC defines affiliation, among other things, in terms of control. Under the SEC's principle, when stock ownership is enough to lead to control, affiliation exists and independence disappears. The NYSE's approach might be characterized as finding that when stock ownership is enough to lead to control, the director is superindependent of management - so much so that the need for paternalistic protection by a rule disappears. Thus, the SEC's view of the proper role of independent directors seems consistent with the second view canvassed earlier: that they should have ties neither with management nor with the fortunes of the company itself. Yet this view of independent directors seems to see them as ideally having no consistent incentives whatsoever. While clearing away visible ties to management interests, it fails to substitute a tie to the interests of any other constituency. Consequently, it is hard to see how such directors can be expected to act in any predictable way other than in avoiding obvious (and punishable) illegalities, and the purpose of having them on the board seems suddenly obscure. The lack of any serious underlying theory of independent director motivation is startlingly manifest. ${ }^{62}$

${ }^{60}$ Notice of Filing of Proposed Rule Change and Amendment No. 1 Thereto by the National Association of Securities Dealers, Inc., Exchange Act Release No. 34-47516 ( Mar. 17, 2003), available at $\mathrm{http}: / / \mathrm{www} . \mathrm{sec} . \mathrm{gov} / \mathrm{rules} / \mathrm{sro} / 34-47516 . \mathrm{htm}$.

${ }^{61}$ See NASD MANUAL: MARKETPLACE RULES $\S 4350(\mathrm{c})(5)$, available at www.nasdaq.com; LISTED COMPANY MANUAL, supra note 4, at Sec. 303.00A.

${ }^{62}$ For an excellent discussion of the implicit or explicit attitude toward equity ownership by independent directors in the various statutes and regulations discussed above, which takes a somewhat different view on some issues, see Chandler \& Strine, supra note 25. As is well known, Fama and Jensen argued that independent directors automatically have an incentive to protect shareholder interests, because those who are executives in other businesses and participants in the managerial labor market have an incentive to develop reputations as experts in decision control. See E.F. Fama \& M.C. Jensen, Separation of Ownership and Control, 26 J.L. \& ECON. 301, 315 (1983). This view seems to overlook the obvious problem that those who in practice appoint directors - that is, CEOsdo not want experts in decision control when the decisions being controlled are their own. Bebchuk 
Independent directors are also called for elsewhere in federal legislation, even though they are not technically so labelled. The Investment Company Act, for example, states that no more than $60 \%$ of an investment company's board may consist of "interested" directors unless the company operates an open-ended fund according to a strict set of criteria. ${ }^{63}$ The presence of non-interested directors on the board is intended "to supply an independent check on management and to provide a means for the representation of shareholder interests in investment company affairs." ${ }^{64}$

The definition of "interested director" is too complex to go into here, ${ }^{65}$ but it essentially captures almost anyone who is connected with or has done business with the company or its investment adviser. The aim of the definition is to ensure independence from those who manage the company's funds. It adopts the view that ownership of the investment company's securities is not per se a factor leading to a finding of interestedness. ${ }^{66}$ Note that "interested director" under this definition is not the obverse of "disinterested director" as defined in state corporate law. ${ }^{67}$

The concept of independent director can even be found in federal tax law. Public concern over excessive executive compensation led Congress to amend the Internal Revenue Code to provide that incentive compensation plans would be subject to a $\$ 1$ million deduction

and his colleagues have challenged the Fama-Jensen view specifically in the context of CEO compensation:

First, the signal provided by independent directorships is likely to be quite noisy, particularly when the board is large and responsibilities are diffuse. Second, and relatedly, the managerial labor market is more likely to focus on the manager's performance in his primary role rather than in his independent directorships. Third, there are likely to be a considerable number of independent directors who are interested less in establishing reputations as "expert decisionmakers" than in keeping their current board seats and perhaps joining other boards. ... CEOs have considerable influence in the choice of independent directors and will tend to prefer candidates who are unlikely to challenge their compensation. Thus, for a director aspiring to additional board positions, the "market" for directors creates incentives not to challenge the $\mathrm{CEO}$ on the issue of his compensation but rather to accommodate the CEO's wishes.

Lucian Arye Bebchuk et al., Managerial Power and Rent Extraction in the Design of Executive Compensation, 69 U. CHI. L. REV. 751, 771 (2002) (footnotes omitted). Needless to say, these doubts about incentives become even stronger when there is a deliberate attempt to remove any incentive to act in the interests of shareholders.

For an interesting theory of director motivation that makes a good case for considering altruistic behavior, see Lynn A. Stout, On the Proper Motives of Corporate Directors (Or, Why You Don't Want to Invite Homo Economicus to Join Your Board), 28 DEL. J. CoRP. L. 1 (2003).

${ }^{63}$ See Investment Company Act of 1940, 15 U.S.C. $§ 80 \mathrm{a}-10$ (2000).

${ }^{64}$ S. REP. No. 91-184 (1969) (legislative history), reprinted in 1970 U.S.C.C.A.N. 4897.

${ }^{65}$ The definition is codified at 15 U.S.C. section 80a-2.

${ }^{66}$ See the "provided" clause at the end of 15 U.S.C. 80a-2(a)(19)(A).

${ }^{67}$ This term is discussed below in Part II.B.3. 
limitation unless administered by a committee of "outside directors," defined essentially to mean directors who could be independent of management. ${ }^{68}$

Independent directors were also present in federal securities law before the SOA. Rule 16b-3 under the SEA gives the board of directors, or a committee of the board composed solely of two or more "Non-Employee Directors," the power to exempt certain trades from the application of Section 16(b) of the SEA regarding short-swing trading profits. ${ }^{69}$ A nonemployee director is defined as a director who

(A) Is not currently an officer (as defined in Rule 16a-1(f)) of the issuer or a parent or subsidiary of the issuer, or otherwise currently employed by the issuer or a parent or subsidiary of the issuer; (B) Does not receive compensation, either directly or indirectly, from the issuer or a parent or subsidiary of the issuer, for services rendered as a consultant or in any capacity other than as a director, except for an amount that does not exceed the dollar amount for which disclosure would be required pursuant to Item 404(a) of Regulation S-K $;^{70}$ (C) Does not possess an interest in any other transaction for which disclosure would be required pursuant to Item 404(a) of Regulation S-K; and (D) Is not engaged in a business relationship for which disclosure would be required pursuant to Item 404(b) of Regulation S-K. ${ }^{71}$

Here is an interesting example of an attempt to use the institution of independent directors to accomplish something for which it is not quite fitted. The point of having independent directors lies in having a group of persons who are always and systematically independent of management. In this spirit, the definition quite properly excludes certain persons who are not employees but who might nevertheless be in some degree beholden to management: lawyers from firms of which the company is a major client, for example. The point of Rule 16b-3, however, is - or should be - to put the power to waive a company's right to recover short-swing trading profits in the hands of persons whose interests are not tied to those of the person who traded. That Rule 16b-3 does not quite accomplish this can be readily

${ }^{68}$ Treas. Reg. $§ 1.16227$ (e)(3)(i) (1995), states: "The performance goal under which compensation is paid must be established by a compensation committee comprised [sic] solely of two or more outside directors." It defines outside director as follows:

(i) ... A director is an outside director if the director-(A) Is not a current employee of the publicly held corporation; (B) Is not a former employee of the publicly held corporation who receives compensation for prior services (other than benefits under a tax-qualified retirement plan) during the taxable year; (C) Has not been an officer of the publicly held corporation; and (D) Does not receive remuneration from the publicly held corporation, either directly or indirectly, in any capacity other than as a director. For this purpose, remuneration includes any payment in exchange for goods or services.

Note once again that this definition is unconcerned with stock ownership by the director, but is concerned with freedom from management influence. Thus, persons "outside" the company still do not count as "outside" directors for the purposes of this regulation if they do business with the company.

${ }^{69}$ Short-swing trading profits are profits "realized ... from any purchase and sale, or any sale and purchase, of any equity security of [an] issuer ... within any period of less than six months[.]" Securities Exchange Act of 1934 (SEA) § 16(b).

${ }^{70}$ The amount in question is $\$ 60,000$.

${ }^{71}$ The provisions of Item 404(b) of Regulation S-K are too complex to go into here, but attempt to capture significant business relationships between the issuer and entities with which its directors are in some way connected. 
seen by noting that a member of the subcommittee with the power to exempt could be (a) the spouse of the person who realized the trading profits, or even (b) the person who actually traded. $^{72}$

The discussion above shows an interesting contrast between United States federal law, which has exacting requirements for independent directors but mandates only a limited function for them, and the rules of the exchanges, which have a looser definition but require that they constitute more than half of the board.

Independent director requirements in other major jurisdictions have been considerably less exacting, although still important. In the United Kingdom, for example, there does not exist, strictly speaking, any independent director requirement at all. Instead, companies listed on the London Stock Exchange are required by its listing rules to disclose, in their annual report and accounts, a statement of how they have applied the principles in Section 1 of the Combined Code. ${ }^{73}$ A company that has not complied must specify the provisions of the code with which it has not complied. Section 1 of the Combined Code provides that non-executive directors should constitute not less than one third of the board, ${ }^{74}$ but these are not the same as independent directors, who should constitute a majority of the non-executive directors. The Combined Code clearly distinguishes them (without rigorously defining them) by stating:

The majority of non-executive directors should be independent of management and free from any business or other relationship which could materially interfere with the exercise of their independent judgement. Non-executive directors considered by the board to be independent in this sense should be identified in the annual report. ${ }^{75}$

Whereas the SOA contemplates a specific role for independent directors only on the board's audit committee, the Combined Code contemplates a role for them on the remuneration committee as well, which is to be composed solely of independent directors. ${ }^{76}$ The audit committee is to have at least three members, all of whom should be non-executive directors. Not all need satisfy the criteria for independence, however-only a majority. ${ }^{77}$ Finally, unlike the SOA, the Combined Code does not call for the remuneration committee or the audit committee to have exclusive jurisdiction over their respective subject matter areas.

${ }^{72}$ Persons who own more than $10 \%$ of a company's stock are subject to the short-swing profit rule of Section 16(b) of the SEA, but could still meet the definition of "Non-Employee Director" if they had no other relationship with the company.

${ }^{73}$ See Financial Services Authority (United Kingdom), The Listing RULES $\uparrow 12.43 \mathrm{~A}$, available at http://www.fsa.gov.uk. The "Combined Code" refers to the "Principles of Good Governance and Code of Best Practice," a document compiled by the Committee on Corporate Governance and derived from its own final report (the Hampel Report), the Greenbury Report, and the Cadbury Report. On the relationship between mandatory state regulation and self-regulation in the United Kingdom, see generally BRIAN R. CHEFFINS, COMPANY LAW: THEORY, STRUCTURE, AND OPERATION 364-420 (Clarendon Press 1997).

${ }^{74}$ See FinANCIAL SERVICES AUthority (UK), PrinciPles of GoOd GOVERNANCE AND CODE OF BEST PRACTICE $§ 1 . A .31$ (2002), available at http://www.fsa.gov.uk [hereinafter Combined Code].

${ }^{75} I d$. at 1.A.3.2.

${ }^{76}$ See id. at $\S$ 1.B.2.2. As I am strictly distinguishing here between independent directors and non-executive directors, who may or may not be independent, I save for the following section a discussion of the nominating committee under the Combined Code, which is to be composed of nonexecutive directors.

${ }^{77}$ See id. at $\S 1 . D .3 .1$. 
They are to make recommendations to the board, but the board is not obliged to follow their recommendations.

Before leaving the subject of independent directors, it is worth examining their role in the German corporate governance system in order to show that independence from management does not necessarily lead to protection of shareholder interests. German law mandates a dual-board system for large publicly-held corporations. Each corporation has an elected supervisory board (Aufsichtsrat), which appoints a managing board (Vorstand) composed of senior corporate managers. The role of the supervisory board is that of overseeing the management of the company, ${ }^{78}$ but its role is limited to just that. Its major powers are the power to appoint and dismiss members of the managing board and the power to represent the company in its dealings with members of the management board. ${ }^{79}$ The law explicitly allocates managerial power to the managing board. ${ }^{80}$ Shareholders can even overrule supervisory board decisions through a three-fourths majority vote. ${ }^{81}$

Since the managing board is, by definition, composed of corporate managers, an examination of independent directors in German corporations must focus on the supervisory board. German corporate law aims to ensure the independence of members from company management by barring legal representatives of enterprises controlled by the company in question as well as legal representatives of other corporations whose supervisory boards include members of the management board of the company in question. ${ }^{82}$

It is by no means intended, however, that supervisors should be independent of all outside influence and should exercise their judgment in pristine isolation from the world around them. On the contrary, as many as one half may, under the German system of codetermination, be employee representatives whose explicit remit is to protect the interests of employees. Others may be representatives of banks and other businesses who are "chosen for the very reason that they are not independent; that is, because they or the particular constituency they represent has an existing financial or similar relationship to the company." ${ }^{83}$ German corporate law in this sense seems clearer about the functions of independent directors (or their equivalent) than United States federal law, which is concerned mainly that a certain number of directors not be beholden to management.

\section{The "Outside" Director}

The concept of outside director is often confused with that of independent director, but it makes sense to distinguish the two, because they can play different roles. By "outside director" I mean here any director who is not a company employee ${ }^{84}$ without regard to

${ }^{78}$ See Aktiengesselschaften [Law on Stock Corporations] § 111(1), translated in COMMERCIAL LAWS OF THE WORLD: GERMANY (rev. ed. 1995).

${ }^{79}$ See Walter Oppenhoff \& Thomas O. Verhoeven, Stock Corporations, in BUSINESS TRANSACtions IN GERMANY, Ch. 24 § 24.03 (Bernd Rüster ed., Matthew Bender 2003).

${ }^{80}$ See Aktiengesselschaften [Law on Stock Corporations], supra note 78, at § 76(1).

${ }^{81}$ See id. at $\S 111(4)$.

${ }^{82}$ See id. at $\S 100(2)$.

${ }^{83}$ Thomas J. André, Jr., Cultural Hegemony: The Exportation of Anglo-Saxon Corporate Governance Ideologies to Germany, 73 TUL. L. REV. 69, 152 (1998).

84 "Outside director" and "non-executive director" are often used interchangeably. I do not use the term "non-executive" director here because on its face such a term could include directors who were employees, but not executives - for example, worker representatives. Such directors would be neither outside directors, in the sense of being able to bring some special expertise to the board not 
whether she meets a standard of independence. The Cadbury Report envisages "a board made up of a combination of executive directors, with their intimate knowledge of the business, and of outside, non-executive directors, who can bring a broader view to the company's activities[.]" ${ }^{85}$ Cheffins notes in a similar vein that one function of outside directors is that of "providing full-time executives with support and assistance as they carry out their managerial tasks, which entails offering specialized advice and fostering links with other organizations." 86

While outside directors as defined above are not part of the American corporate law scene, at least in terms of mandatory requirements, they do have a role to play in British corporate governance. As noted above, the Combined Code, the degree of compliance with which must be disclosed by companies listed on the London Stock Exchange, calls for one third of the board to be composed of outside directors. ${ }^{87}$

Japanese corporate law also uses the concept of "outsideness" for directors and auditors (kansayaku). Companies meeting the statutory definition of "large" 88 must have a board of statutory auditors, and more than half the members must be "outside auditors" (shagai kansayaku) - that is, they must not have been directors, managers, controllers, or employees of the company prior to their appointment. ${ }^{89}$ Note that this definition does not exclude those who personally or through their employer do a large amount of business with the company, and thus does not match most definitions of "independence." Although recent reforms ${ }^{90}$ have been intended to strengthen the supervisory role of the board of auditors, it is

otherwise available to the company, nor independent directors, in the sense of feeling free to oppose management. Because the role of such employee directors is very different from the role of nonemployee non-executive directors, I do not favor using a term that on its face encompasses them both.

${ }^{85}$ CADBURY REPORT, supra note 21, at 94.1 .

${ }^{86}$ CHEFFINS, supra note 73 , at 96.

${ }^{87}$ The Combined Code calls them "non-executive directors", but specifically contemplates that some will not meet a criterion of independence. Although the Combined Code does not specifically exclude employees from the scope of non-executive directors, that seems to be the intention. Something akin to a legislative history of these provisions of the Combined Code can be found in the Cadbury Report, from which they are largely taken. Dahya and McConnell, in their study of outside directors in British companies, state that they consider a director an outsider "if he/she is listed as a 'non-executive' director, he/she is not related to the company's controlling family, and he/she was not employed by the company historically." Dahya \& McConnell, supra note 10, at 9.

88 "Large" is defined in Art. 1.2 of the Audit Special Exceptions Law as having capital of 500 million yen or debts of 20 billion yen. Kabushiki gaisha no kansa nado ni kansuru shōhō no tokurei ni gansuru hōritsu [Law Concerning Special Exceptions to the Commercial Code Respecting Audit and Other Matters of Stock Companies] 2003 (Japan) [hereinafter Audit Special Exceptions Law].

${ }^{89}$ See id., Art. 18. Prior to revisions to the Commercial Code in 2001, prior involvement with the company more than five years prior to appointment was not a bar to outsideness.

${ }^{90}$ On recent reforms, see generally Motomi Hashimoto, Commercial Code Revisions: Promoting the Evolution of Japanese Companies (Nomura Research Institute, NRI Papers, No. 48, May 1, 2002); Ministry of Justice [Japan], Japanese Corporate Law: Drastic Changes in 2000-2001 \& The Future (2002), available at http://unpan1.un.org/intradoc/groups/public/documents/apcity/unpan010252.pdf and http://www.moj.go.jp/ENGLISH/CIAB/jc101-1.html; Andrew Peaple, Japan's New Commercial Code, 7 The Financial Regulator (No. 3, Dec. 2002) 66; Suenaga Toshikazu \& Fujikawa Nobuo, Atarashii kooporeeto gabanansu to kigyō keiei [The New Corporate Governance and Enterprise Operations], TORISHIMARIYAKU NO HŌMU [Directors' Legal Affairs], No. 108, Mar. 2003, at 46-57; 
not clear that they will have much effect. Auditors have few concrete powers - they can bring suit against management and block certain resolutions of the board of directors - but these are exercised rarely. ${ }^{91}$ Moreover, they are nominated by the board of directors - the very people they are supposed to supervise.

The definition of outside director is similar: "a person who is currently a director but who is not executing any company business, who has not in the past been a director, manager or other employee executing any business of the company or its subsidiaries, and who currently is neither executing any business of a subsidiary nor is a manager or any other employee of the company or its subsidiaries." ${ }^{92}$ Like the concept of outsideness applied to auditors, this concept of outsideness does not exclude persons such as lawyers, suppliers, and others who may do large amounts of business with the company. ${ }^{93}$

The distinction between independence and outsideness seems to be well understood in Japan - the Revised Corporate Governance Principles of the Japan Corporate Governance Forum, for example, clearly differentiate the two. ${ }^{94}$ Prior to recent corporate law reforms, the concept of outsideness might, however, have been more appropriate than one of independence. The only purpose it served was to define what sort of director could be subject to a more forgiving standard of care, ${ }^{95}$ and therefore it is reasonable to focus on those who are not intimately acquainted with the affairs of the company as opposed to those who are not dependent in some way upon management's favor. In the 2002 corporate governance reforms that became effective in April, 2003, however, outside directors are expected to play a role more akin to that expected of independent directors in United States federal securities law: companies may opt into a U.S.-style corporate governance structure in which outside

Eiji Takahashi \& Tatsuya Sakamoto, The Reform of Corporate Governance in Japan: A Report on the Current Situation, 14 JOURNAL OF INTERDISCIPLINARY ECONOMICS 193 (2003). 2003).

${ }^{91}$ Personal communication with Prof. Curtis J. Milhaupt, Columbia Law School (Sept. 26,

${ }^{92}$ Shōhō [Commercial Code of Japan], Art. 188(2)(7.2), as adapted from translation in Hashimoto, supra note 90 , at 9.

${ }^{93}$ Note that this definition is not the definition of outsideness used in Miwa and Ramseyer's study of outside directors and corporate performance in Japan. Their definition includes anyone with past or concurrent careers at other institutions, apparently notwithstanding past employment at the company in question. See Miwa \& Ramseyer, supra note 26.

${ }^{94}$ See JAPAN CORPORATE GOVERnANCE ForUM, supra note 33. Principle 6.3 states: "The majority of directors on the nominating committee and the compensation committee should be outside directors, and there should be one or more independent directors. The majority of audit committee members should be independent directors." Principle 4 states:

1. An outside director is someone who is not and has never been a full-time director, executive, or employee of the company or its parent company, subsidiaries or affiliates (collectively, the "Company etc.").

2. An independent director is someone who can make decisions completely independently from the managers of the Company etc., and therefore necessarily does not hold any interest with respect to the company.

${ }^{95}$ See Shōhō [Commercial Code of Japan], Art.266(18) (providing that shareholders may by resolution reduce an outside directors' maximum liability to the company to twice her annual director's income, as opposed to four times the annual income for ordinary directors and six times annual income for representative directors (daihyō torishimariyaku)). See generally Hashimoto, supra note 90 , at 9 . 
directors are required to be present on nominating committees, audit committees, and compensation committees. ${ }^{96}$

\section{The "Disinterested" Director}

Far more important than federal law in the United States for purposes of internal corporate governance is state law, and this for the most part - at least in terms of economic impact - means the law of Delaware. United States corporation law at the state level does not in fact generally provide for the institution of independent directors as such or define them. ${ }^{97}$ Instead, state corporate statutes focus on particular conflict-of-interest transactionstransactions, for example, between a corporation and one of its directors or officers, or between a corporation and another entity in which one of its directors or officers has an interest, or the taking by corporate officers of business opportunities that arguably belong to the corporation - and provide that certain consequences will follow depending on whether or not those with decisionmaking power who have a conflict of interest recuse themselves from the decisionmaking process.

To understand the state statutes, it is important to understand the common law rule that would operate if such statutes did not deal with conflict-of-interest transactions. The common law rule in many states in the late $19^{\text {th }}$ century was quite absolute: many conflict-ofinterest transactions could be set aside at the instance of any stockholder. ${ }^{98}$ State statutes, then, typically operate by specifically displacing the common law rule on conflict-of-interest transactions and permitting them provided certain conditions are met. These conditions usually pertain to disclosure of the conflict of interest and approval of the transaction by disinterested decisionmakers, whether directors or shareholders. ${ }^{99}$

${ }^{96}$ See Hashimoto, supra note 90, at 10.

${ }^{97}$ A limited exception can be found in Michigan, where corporations may, subject to certain requirements, designate one or more directors as "independent directors," at which point certain statutory consequences follow. It was the intention of the drafters to put in place a mechanism for preventing management abuses before they occurred, instead of remitting them to costly after-the-fact shareholder litigation. The extent to which such designated independent directors have been treated by the courts differently from "disinterested directors" under traditional state corporate law principles is, however, beyond the scope of this paper. For an introduction to the Michigan statutory scheme, see Scott J. Gorsline, Statutory "Independent" Directors: A Solution to the Interested Director Problem?, 66 U. DET. L. REV. 655 (1989) and Cyril Moscow et al., Michigan's Independent Director, 46 Bus. LAW. 57 (1990).

${ }^{98}$ See, e.g., Wardell v. Railroad Co., 103 U.S. 651, 658 (1880) ("The law, therefore, will always condemn the transactions of a party on his own behalf when, in respect to the matter concerned, he is the agent of others, and will relieve against them whenever their enforcement is seasonably resisted."). Note that the law did not prohibit such transactions. Like many "rules" of company law, this rule is simply the provision of a private cause of action, not an outright prohibition. The common law rule made conflict-of-interest transactions very vulnerable to attack by shareholders. The person with the conflict of interest would then bear liability for returning the corporation to the status quo ante.

${ }^{99}$ It is important to note that if the conditions are not met, the transaction is not for that reason unlawful. It merely means that a court may apply the common law rule to the transaction if a shareholder brings suit to set it aside. But the common law rule is whatever the court says it is, and it is not at all clear that American courts of the early $21^{\text {st }}$ century will find such transactions as offensive per se as did American courts of the $19^{\text {th }}$ century. Thus, modern state corporation statutes provide a safe harbor for conflict-of-interest transactions, but one cannot assume that transactions falling outside the safe harbor are necessarily all barred. See, e.g., Marciano v. Nakash, 535 A.2d 400 (Del. 1987) (upholding on fairness grounds a self-dealing transaction that did not meet the requirements of Section 
The Delaware General Corporation Law announces in Section 144 that a transaction in which a director or officer stands on both sides ${ }^{100}$ shall not be voidable by reason of a conflict of interest if one of the following conditions are met: (1) the relevant facts are known to the board and a majority of disinterested directors approve; or (if, for example, the entire board has a conflict of interest) (2) the relevant facts are known to the shareholders, and the shareholders approve; ${ }^{101}$ or (if for any reason neither of the first two occurs) (3) the terms of the transaction are, as of the time it is authorized by the directors or the shareholders, fair to the corporation.

Note that the while the first two safe harbor provisions are procedural, the third is substantive and in effect throws out the old common law rule almost entirely. ${ }^{102}$ Even without disclosure or recusal, an interested director can wait until a conflict-of-interest transaction is discovered, and then defend it on the grounds of fairness. Whether the need to defend on grounds of fairness is a bulwark against managerial self-dealing depends on one's confidence in the ability of shareholders to bring suits and of courts to make a sound judgment on the issue.

The Model Business Corporation Act has an entire subchapter (Subchapter F) devoted to directors' conflicting interest transactions. ${ }^{103}$ After defining "conflicting interest transaction" at great length, the MBCA provides that a shareholder shall not have a cause of action for damages, injunction, or any other remedy, either in his own name or the name of the corporation, on the grounds of the existence of a conflict of interest provided that one of

144, the Delaware safe-harbor statute). See also Fliegler v. Lawrence, 361 A.2d 218 (Del. 1976) (refusing to view the Delaware safe-harbor statute as either completely pre-emptive of the commonlaw duty of director fidelity or as constituting a broad grant of immunity). In Fliegler, the defendants had general shareholder approval of the challenged transaction, but not disinterested shareholder approval; they argued that Section 144 required only the former and not the latter. Without directly addressing the defendants' argument, the court held that Section 144 merely removed the "interested director" cloud upon the transaction, but did not sanction unfairness or remove the transaction from judicial scrutiny. See id. at 222. Without the "interested director" cloud, however, it is hard to see why the business judgment rule should not have applied.

${ }^{100}$ The statutory definition is more complicated, but this simplified version will do for present purposes.

${ }^{101}$ The Delaware statute, deliberately or not, contains no requirement that shareholder approval be by disinterested shareholders only, but the Delaware Supreme Court has occasionally (perhaps carelessly) read this requirement into the statute. See, e.g., Marciano v. Nakash, 535 A.2d 400, 405 n.3 (Del. 1987) ("[A]pproval by fully-informed disinterested directors under section 144(a)(1), or disinterested stockholders under section 144(a)(2), permits invocation of the business judgment rule and limits judicial review to issues of gift or waste with the burden of proof upon the party attacking the transaction.") (dictum); Cede \& Co. v. Technicolor, 634 A.2d 345, 366 n.34 (Del. 1993) (citing Marciano to the same effect) (dictum). Fliegler, supra note 99, comes very close to holding that such a requirement exists; on the other hand, it still finds that the challenged transaction was fair.

102 Only "almost" because where the plaintiff can show a conflict of interest, the burden of proving fairness (or any of the other safe harbor elements) is on the defendant.

${ }^{103}$ Because state statutes modeled on the MBCA will be, like the Delaware rule, situated within an existing common law regime, the MBCA specifically disclaims its intention to do anything other than deal with challenges based on conflicts of interest by directors. It does not, for example, permit or forbid challenges based on other grounds, or address the duties owed, if any, by controlling shareholders to minority shareholders. All those issues it leaves to the state's existing common law jurisprudence. 
the following applies: (1) there was sufficient disclosure followed by approval of a majority of disinterested directors; or (2) there was sufficient disclosure followed by approval of a majority of shares owned by disinterested shareholders; or (3) the terms of the transaction are, as of the time it is entered into, fair to the corporation. Although the actual provisions are far more complex than this brief summary, it can be seen that the MBCA rules are essentially the same as the DGCL rule except for the additional requirement that shareholder approval be by disinterested shareholders - a requirement that may in any case already exist in Delaware as a matter of case law. ${ }^{104}$

In short, both the DGCL and the MBCA have a concept of independence, but it amounts only to disinterest in a particular conflict-of-interest transaction-something quite different from abstract independence. Both attempt to deal with such transactions generally through disclosure to and approval by directors who are not involved in the transaction. But they do not assume that such directors will always be the same person, and do not require the institution of abstractly independent directors. Instead, they take a transaction-by-transaction approach, and ask in each case whether there was approval by directors (or other decisionmakers) who were disinterested in the transaction in question. The Delaware judiciary has stressed the preferability of case-by-case analysis over the application of abstract definitions on several occasions - when asked how a court would determine whether a board had acted independently, the Chief Justice of the Delaware Supreme Court replied,

We can't set down rules for independence. In Delaware, we're a judicial body, not a legislative one. ... But we didn't just fall off the turnip truck, you know. We can tell whether somebody is acting independently or not. I don't think, for instance, that lawyers who get substantial fees from a corporation can be considered independent directors for most purposes, although they might be for some. ${ }^{105}$

Recent cases have also stressed the need for a fact-intensive inquiry. ${ }^{106}$ Although this approach has costs, it also has hidden savings: the cost of policing an abstract independence requirement in the many companies where it will never be needed. The Delaware approach has the advantage of dealing directly with the problem as it arises. Indeed, abstractly independent directors (defined by their lack of connection to management) may themselves have a conflict of interest in particular corporate transactions; it seems best to examine each transaction as it comes. ${ }^{107}$

${ }^{104}$ See note 101 supra.

${ }^{105}$ What's Wrong with Executive Compensation, HARV. BUS. REV., Jan. 2003, at 68.

${ }^{106}$ See, for example, In re Oracle Corp. Derivative Litigation, 824 A.2d 917, 937 (2003), in which Vice Chancellor Strine spoke of Delaware's "flexible, fact-based approach to the determination of directorial independence," and added:

This contextual approach is a strength of our law, as even the best minds have yet to devise across-the-board definitions that capture all the circumstances in which the independence of directors might reasonably be questioned. By taking into account all circumstances, the Delaware approach undoubtedly results in some level of indeterminacy, but with the compensating benefit that independence determinations are tailored to the precise situation at issue.

Id. at 941. See also Krasner v. Moffett, 826 A.2d 277, 286 (Del. 2003) (Veasey, C.J.) ("The independence of the special committee involves a fact-intensive inquiry that varies from case to case.").

${ }^{107}$ This approach is also adopted in the thoughtful Gainan Avilov et al., General Principles of Company Law for Transition Economies, 24 J. CORP. LAW 190 (1999). 
Of course, deciding on specific self-dealing transactions is not the only reason to have independent directors. The main justification from a public-policy perspective lies in the notion that they will be less conflicted than management in representing shareholder interests in general, since they will not be concerned with preservation of their own jobs as would employee directors. Employee directors will, in the nature of things, be either the chief executive officer or someone under her; this is unquestionably an issue of legitimate concern to shareholders. But state corporate law in the United States generally leaves this up to corporations themselves to decide; a corporation can have many, few, or no independent directors, and investors can make their own decisions about whether to invest. ${ }^{108}$

Finally, we should not overlook management's own interest in having directors who are independent in the sense of being disinterested in particular issues they review as well as being unaffiliated with management or the company more generally. If a board is dominated by management, why would management ever want independent directors on it? There are a few answers, of course: it might be that this is a bonding device whereby management signals to potential investors that it is willing to be monitored effectively, and thereby reduces the firm's cost of capital, making it more competitive with other firms and thus more likely to survive. ${ }^{109}$

Another answer, however, is that management engages independent directors in order to protect itself from liability in shareholder suits. ${ }^{110}$ A company's management often does, and sometimes must (for example, in the case of compensation), engage in transactions that either are or look very much like self-dealing or in some other way implicate a conflict of interest. In such cases the blessing of directors who are both disinterested in the transaction in question and independent of management can be invaluable. As noted above, corporate statutes in the United States do not prohibit self-dealing transactions outright and do not even necessarily require approval by independent and disinterested directors. Instead, they provide a safe harbor for transactions that are approved by directors who are disinterested in the transaction in question. The good-faith use by management of such directors is recognized by courts and extremely valuable. ${ }^{111}$

${ }^{108}$ Noted corporate governance expert Ira Millstein probably overstated the case for a disclosure-only approach to conflicts of interest when he remarked, apropos of several questionable transactions by Disney (which had hired him as a governance advisor), "As long as you tell everybody what you're doing, that's good governance." See Louis Lavelle, More Insiders at the Castle, Bus. WK., Dec. 30, 2002, at 14. For a report of an experiment suggesting that people do not adequately take into account what they know about conflicts of interest, and that conflicted advisors actually give worse advice when they know the recipient is aware of their conflict of interest, see James Surowiecki, The Talking Cure, THE NEW YORKER, Dec. 9, 2002, at 54.

${ }^{109}$ This is essentially the story told by law-and-economics scholars such as Easterbrook and Fischel in FranK EASTERBROOK \& DANIEL FisCHEL, THE ECONOMIC STRUCTURE OF CORPORATE LAW (Harvard Univ. Press 1991).

${ }^{110}$ This is the view of Miwa and Ramseyer, who label such suits "legalized extortion." Miwa \& Ramseyer, supra note 26. Lawrence Mitchell agrees that outsider-dominated boards have the effect of protecting directors from liability, but takes the opposite position on the desirability of that effect, calling it "essentially a fraud". See Lawrence E. Mitchell, The Trouble With Boards (GWU Law School Public Law Research Paper No. 159, Sept. 9, 2005), available at $\mathrm{http} / / / \mathrm{ssrn} . \mathrm{com} / \mathrm{abstract}=801308$. On the insulating effect of disinterested directors generally, see Chandler \& Strine, supra note 25.

${ }^{111}$ Norman Veasey, the Chief Justice of the Delaware Supreme Court, recently warned: 
More specifically, independent and disinterested directors are of vital importance in shareholder derivative litigation. Zapata v. Maldonado ${ }^{112}$ established the Delaware rule that a subcommittee of the board could dismiss shareholder derivative litigation even where demand on the board as a whole was deemed futile provided it could show independence, good faith, and reasonableness. In Delaware, however, the burden is on the corporation to make these showings, and a court is not required to defer even when the corporation meets its burden; it may elect to apply its own "independent business judgment" and consider matters of public policy as well as the corporation's best interests. Nevertheless, it is rare that motions to dismiss in such circumstances are rejected. Other states have adopted even more deferential standards: the Indiana Supreme Court recently held that the decision of a disinterested committee, regardless of demand futility, was conclusive unless the shareholder could show a lack of disinterest or good faith. ${ }^{113}$

\section{CONCLUSION}

There is more at stake in strictly distinguishing the various types of NMDs than the appeal of intellectual order; there are practical consequences as well. Not only are the various types of NMD capable of performing quite different functions, depending upon how they are defined, but the practical effect of any NMD requirement can differ greatly with the definition used as well.

Consider, for example, the difference in the United States between the enforcement mechanisms backing up independent director requirements and those backing up disinterested director requirements. The jurisprudence of disinterested directors is far more developed than that of independent directors. An important reason is that disinterested directors are a concept in Delaware's corporate law, and Delaware has courts and a responsive legislature that sees problems and responds to them. The NYSE rules, by contrast, carry with them no system for spotting problems and resolving disputes through a fair process resulting in written decisions. The same applies to the rules of the SOA: they come from a source that cannot be changed

I would urge boards of directors to demonstrate their independence, hold executive sessions, and follow governance procedures sincerely and effectively, not only as a guard against the intrusion of the federal government but as a guard against anything that might happen to them in court from a properly presented complaint.

What's Wrong with Executive Compensation, supra note 105. That Chief Justice Veasey has a point is demonstrated by the respective outcomes of the management buyouts of Macmillan, Inc. and RJR Nabisco, Inc. In the Macmillan case, senior management engaged in the buyout exercised control over the process through such means as picking the board committee that was to negotiate the terms of the deal with them; as a result, the board was found to have breached its fiduciary duties in accepting management's bid even though it was nominally higher than a competing bid. See Mills Acquisition Co. v. Macmillan, Inc., 559 A.2d 1261 (Del. 1988). In the RJR Nabisco buyout, by contrast, the president and CEO leading the buyout group had no role in the selection of the board committee, and the members of that committee had no direct or indirect financial interest in the transaction. As a result, although the board rejected a nominally higher bid, its decision was deemed protected by the business judgment rule. See In re RJR Nabisco, Inc. Shareholders Litigation, [1988-1989 Transfer Binder] Fed. Sec. L. Rep. (CCH) $₫ 94,194$ (Del. Ch. 1989). For a detailed discussion of the two cases, see Stephen M. Bainbridge, Independent Directors and the ALI Corporate Governance Project, 61 GEO. WASH. L. REV. 1034, 1076-79 (1993).

112430 A.2d 779 (Del. 1981).

${ }^{113}$ See In re Guidant Shareholders Derivative Litigation, __ N.E.2d__ , 2006 WL 242596 (Ind. 2006). 
quickly. ${ }^{114}$ Furthermore, if Delaware wants disinterested directors, it can give incentives to shareholders to sue if they don't get them. But the exchanges have only the blunt tool of delisting for the enforcement of their rules. Thus, there is simply far less legal material out there analyzing the issue of independence for the purpose of compliance with stock exchange and similar rules, as opposed to the issue of disinterest for the purpose of resolving shareholder litigation under state law.

Furthermore, whereas disinterest is something that is argued about after the fact, and may never even come up as an issue if shareholders never sue, independence is something that needs to be determined in the abstract, apart from any concrete decision, and must persist over time. This implicates two issues. The first is that of cost. Although Delaware law gives an important role to disinterested directors, the Delaware authorities need not spend a penny on ascertaining whether any particular director is disinterested unless a particular dispute arises. Thus, there is no need to spend resources on companies where problems do not arise; the existence of a dispute signals the existence of a problem (regardless of which party is ultimately determined to be right). Moreover, when a dispute arises it is quite within the province of courts to make careful and individualized determinations of the disinterestedness of particular directors with respect to the challenged conflict-of-interest transaction. While prevention is often considered superior to after-the-fact remediation, the latter approach offers some significant cost savings of its own.

The second issue is that of effectiveness. Here the question is whether, given the many and subtle ties that may exist between nominees and company management, independence can really be ascertained in the abstract on the basis of paper submissions by management, and whether independence so ascertained is really very meaningful. ${ }^{115}$

Finally, it is crucial to take account of the institutional landscape in thinking about the effectiveness of different models of the NMD in different jurisdictions. However Congress may have contemplated that the independent director requirements of the SOA would be enforced - through SEC action, through private litigation under the federal securities laws, or through some other method - it is important to note the possible interplay of state law with federal law here. Law firms are already warning their clients that penalties in one forum can turn into penalties in another. For example, the SOA mandates the stock exchanges to require corporations to adopt internal governance rules on pain of delisting. A director might well not be protected by the business judgment rule for actions she took that resulted in delisting; she

${ }^{114}$ The arguments in this paragraph are made more fully in Chandler \& Strine, supra note 25.

${ }^{115}$ The Special Litigation Committee directors found insufficiently independent in In re Oracle Corp. Derivative Litigation, 824 A.2d 917 (Del. Ch. 2003), for example, would have passed any existing objective test of independence, but because they and the defendant directors shared ties with Stanford University, the Delaware Court of Chancery found "a social atmosphere painted in too much vivid Stanford Cardinal red for the SLC members to have reasonably ignored it." Id. at 947. Similarly, Richard Breeden notes that the chairs of WorldCom's compensation committee and audit committee (like $80 \%$ of the board in the Ebbers era) both satisfied contemporary definitions of "independence," and would probably have satisfied the proposed NYSE and Nasdaq definitions. See RichaRd C. BREEDEN, RESTORING TRUST: REPORT TO THE HON. JED S. RAKOFF, THE UNITED STATES District COURT FOR THE SOUTHERN DISTRICT OF NEW YORK, ON CORPORATE GOVERNANCE FOR THE FUTURE OF MCI, INC. (2003), at http://www.thecorporatelibrary.com/spotlight/scandals/Restoring_Trust_Final-WorldCom.pdf. Nevertheless, they had both been involved in business with CEO Bernard Ebbers for years, and "seemed to be more solicitous of Ebbers' wishes than shareholder interests." Id. at 28 n. 27, 30. 
might be held to have a fiduciary duty to prevent such an occurrence. ${ }^{116}$ As Chandler and Strine predict,

[I]t is unlikely that stockholder plaintiffs will be content to leave enforcement of the 2002 Reforms entirely to the SEC and the [New York Stock] Exchange. Rather, if history is any guide, the active plaintiffs' bar will be creative and aggressive in deploying the Reforms itself as a tool in shareholder litigation under state law. ${ }^{117}$

In the United States, therefore, one can see that the requirements of the SOA are already being viewed by judges, plaintiffs' lawyers, and defendants' lawyers in terms of their liability implications in the hands of different institutions. The familiar tool of state-law fiduciary duty litigation may end up being the vehicle for the enforcement of norms stated in federal law or stock exchange rules. But this and other vehicles may be absent in other jurisdictions contemplating a borrowing of American rules on NMDs, whether defined as independent or as disinterested directors. ${ }^{118}$

A further practical consequence of confusion about the different roles to be played by NMDs is the difficulty for interpreters of the rules such as courts to figure out legislative intent. As demonstrated above, federal law cannot seem to make up its mind about whether substantial shareholding by independent directors is good or bad. Thus, a court or administrative agency will have little to guide it when deciding issues such as whether, for example, shareholding by someone affiliated with a director should be aggregated with that director's shareholding for the purpose of applying some rule.

This article began by noting the popularity of the institution of NMDs despite the shaky empirical support for their effectiveness. It then showed that in many cases, we do not even know quite what we mean when we talk about various models of the NMD, and that we often do so carelessly. It is easy to say that jurisdictions planning to borrow the institution of NMDs should take care to know exactly what it is they are borrowing. Equally important, however, is that jurisdictions already using the institution should clarify the purposes to be served and adjust the legal definitions accordingly.

${ }^{116}$ See, e.g., Memorandum, Weil, Gotshal \& Manges LLP, Director Liability Warnings from Delaware (Jan. 10, 2003).

${ }^{117}$ See Chandler \& Strine, supra note 25.

${ }^{118}$ While China has borrowed the independent director requirement, for example, it is not possible for shareholders damaged by a lack of appropriate independence on the part of a given director to sue anyone for it. See Clarke, supra note 8, at 